\title{
International Journal of Communications and Networks
}

(ISSN:2637-6571)

\section{FACT-CHECKING: AN IMPORTANT TOOL TO COMBAT FAKE NEWS ON HEALTH IN COVID-19 PANDEMIC}

\section{Esther Gomes Muniz Rocha1*, Josué Miguel de Oliveira', Kelly Cristina Pereira de Araújo, Maria Eduarda Santos Teperino Abreu'1, Mariana Rodrigues Sandes da Silva1', Thais Ranielle Souza de Oliveira'.}

\section{${ }^{1}$ Centro Universitário Euro-Americano (UNIEURO)}

\section{ABSTRACT}

Objective: To demonstrate the importance of Fact-Checking tools in combating health fake news in the COVID-19 pandemic.

Methods: Quantitative descriptive study, conducted during the *Correspondence to Author: Sars-Cov-2 pandemic. Fake news were accounted and identified Esther Gomes Muniz Rocha through the website chequeado.com, registered in the Agência Lupo and Aos Fatos checking platforms, belonging to the International Fact-Checking Network, an international understanding with recognized news verification methodologies. The registered news originated from the social media/networks Facebook, Whatsapp, Instagram, Twitter, and websites. They were later classified according to content in Conspiracy Theory, Prevention/Treatment/Cure, Authorities/Agency Measures, Situation of a city, state and country, Causes, Symptoms, Public Figure and False Context. Results: 529 fake news about coronavirus were obtained, of these 306 were from the Agência Lupo platform, and 223 from the Aos Fatos platform. A total of 99 (18.72\%) fake news were about Conspiracy Theory 99 (18.72\%) Authorities/ Agency Measures and 98 (18.53\%) False Context. As for the origin of fake news 382 (72.21\%) were from Facebook and 67 (12.66\%) from Whatsapp. Conclusion: The Fact-Checking tools in combating misinformation on social networks are important because they deny false news, unlikely allegations, and no justification related to the Covid-19 pandemic. These check sites alert Centro Universitário Euro-Americano (UNIEURO)

How to cite this article:

Esther Gomes Muniz Rocha, Josué Miguel de Oliveira, Kelly Cristina Pereira de Araújo, Maria Eduarda Santos Teperino Abreu, Mariana Rodrigues Sandes da Silva, Thais Ranielle Souza de Oliveira. FACT-CHECKING: AN IMPORTANT TOOL TO COMBAT FAKE NEWS ON HEALTH IN COVID-19 PANDEMIC.International Journal of Communications and Networks, 2021, 4:10. social networks, policymakers, and the public to create measures that educate and protect the integrity and health of individuals and prevent them from falling victim to misinformation.

Keywords: Pandemia. Fake News. Covid-19.

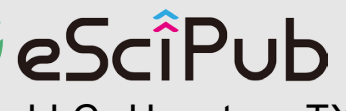

eSciPub LLC, Houston, TX USA. Website: https://escipub.com/ 